\title{
Fracture Behavior of Monazite-Coated Alumina Fiber-Reinforced Alumina-Matrix Composites at Elevated Temperature
}

\author{
Peng-Yuan LEE, ${ }^{\dagger}$ Masamitsu IMAI and Toyohiko YANO \\ Research Laboratory for Nuclear Reactors, Tokyo Institute of Technology, 2-12-1, O-okayama, Meguro-ku, Tokyo \\ $152-8550$
}

\author{
ホットプレス法により作製した $\mathrm{LaPO}_{4}$ 被覆アルミナ繊維/アルミナマトリックス複合材の \\ 高温機械的性質 \\ 李 鵬遠 ${ }^{\dagger}$ 今井雅三 · 矢野豊彦 \\ 東京工業大学原子炉工学研究所, 152-8550 東京都目黒区大岡山 2-12-1
}

\begin{abstract}
High-temperature strength, fracture behavior and microstructure were observed for monazite-coated alumina fiber-reinforced alumina matrix composites hot-pressed at $1200-1300{ }^{\circ} \mathrm{C}$. The composites with $27-41$ vol\% alumina fiber showed no significant change in strength at $25-1100^{\circ} \mathrm{C}$. However, the strength of the composites decreased markedly at a test temperature higher than $1100^{\circ} \mathrm{C}$. The composites hot-pressed at a temperature lower than $1250^{\circ} \mathrm{C}$ fractured in a pseudoductile manner in the test temperature range from $25^{\circ} \mathrm{C}$ to $1100^{\circ} \mathrm{C}$. Young's modulus of the elastic region decreased with increasing test temperature. These composites showed larger deformation at a test temperature above $1100^{\circ} \mathrm{C}$. On the other hand, the composites hot-pressed at more than $1250^{\circ} \mathrm{C}$ fractured in a brittle manner at $25^{\circ} \mathrm{C}-1200^{\circ} \mathrm{C}$ of test temperature. The fracture energy of the composite increased with increasing test temperature and decreased with sintering temperature.
\end{abstract}

[Received May 19, 2004; Accepted September 22, 2004]

Key-words : Fiber-reinforced alumina/alumina composites, High-temperature mechanical properties, Hotpressing, Monazite

1. Introduction

The development of ceramic-fiber-reinforced ceramicmatrix composites (CMCs) is promising for realizing structural materials combining high strength with improved fracture toughness and damage tolerance. Considerable research efforts have been made on the optimization of a CMC material system recently; including nonoxide CMCs and all-oxide CMCs. Because of the susceptibility of nonoxide CMCs in a high-temperature oxidizing environment, all-oxide CMCs, such as the alumina/alumina system, have been highly expected and have become a strong candidate to meet the mechanical and chemical/thermal requirements for high-temperature applications, because they are inherently stable with oxygen and offer an advantage over current commercially available nonoxide ceramic-matrix composites. ${ }^{1,2)}$

It is well known that the properties of the interface between the matrix and the reinforcement are essential in all types of fiber-reinforced ceramic-matrix composite. Fiber coating has been confirmed as an effective way to protect fibers from bonding with the matrix during sintering and to achieve debonding and pullout of fibers from matrix during the fracture of dense matrix composites. ${ }^{3)-6)}$ For an $\mathrm{Al}_{2} \mathrm{O}_{3} / \mathrm{Al}_{2} \mathrm{O}_{3}$ system, many experimental results have shown that monazite is a suitable interface compound for achieving fiber debonding and pullout, since it forms an effective crack deflection layer, and shows high-thermal and chemical stabilites with alumina. ${ }^{7)-12)}$ Furthermore, it can withstand a high temperature for a longtime exposure, e.g., at $1200^{\circ} \mathrm{C}$ for $1000 \mathrm{~h}^{13), 14)}$

In the previous study, a coating technique for fabric

\footnotetext{
† Now with Nagaoka University of Technolgy, 1603-1, Kamitomioka, Nagaoka-shi 940-2188

現在 : 長岡技術科学大学極限エネルギー密度工学研究センター, 940-2188 新潟県長岡市上富岡町 1603-1
}

cloths was developed. ${ }^{15)}$ The uniform coating of all fibers in bundles or cloths to achieve better pseudoductility of the composites has been achieved. ${ }^{16)}$ Furthermore, the effects of fabrication conditions on the room-temperature (RT) mechanical properties of composites using coated fibers were examined. ${ }^{17)}$ However, the temperature of the practical application environment of these composites is generally very high (e.g., above $1000^{\circ} \mathrm{C}$ ), thus, the mechanical properties of the composites at a high temperature should be assessed. Therefore, in this study, we evaluate the influences of sintering condition and fiber volume fraction on the high-temperature mechanical properties of the monazite-coated alumina fiberreinforced alumina composites.

\section{Experimental procedures}

Details of the fabrication processes of the composites are described elsewhere, ${ }^{15)-17)}$ and simply introduced as follows. The fiber used in this experiment was two-dimensionally woven $\left(0^{\circ} / 90^{\circ}\right) \alpha$-alumina fabric cloth (Nextel 610, 99 mass $\%$ $\mathrm{Al}_{2} \mathrm{O}_{3}, 3 \mathrm{M}$ Co., Ltd., USA). One bundle consisted of 420 fibers and the fiber diameter was approximately 10-12 $\mu \mathrm{m}$. The density, tensile strength and elastic modulus of the as-supplied fiber are reported to be $3.9 \mathrm{~g} / \mathrm{cm}^{3}, 3.3 \mathrm{GPa}$ and 375 $\mathrm{GPa}$, respectively. After desizing, the cloths were dipped into $0.07 \mathrm{~mol} / 1$ concentration monazite slurry of $\mathrm{pH} 7$. A rotary pump was used to enhance slurry infiltration into fiber bundles, which were then dried. This dipping and drying process was repeated 10 times, and the coating was finally solidified at $600^{\circ} \mathrm{C}$ for $1 \mathrm{~h}$. Following that, the coated cloths were infiltrated by 5 mass $\% \alpha$-alumina $(99.99 \%, 180 \mathrm{~nm}$, Taimei Chemical) suspension. The impregnated fabric cloths were laminated alternately with alumina green sheets, which were separately prepared using the doctor blade method. Then the stacked alumina-cloths/alumina-green sheets were pressed using a die 
at $20 \mathrm{kPa}$ and heated at $300^{\circ} \mathrm{C}$ for $24 \mathrm{~h}$ in air. Finally, they were hot-pressed at $1200-1300^{\circ} \mathrm{C}$ at $40 \mathrm{MPa}$ applied pressure in $\mathrm{Ar}$ atmosphere for $1 \mathrm{~h}$ in a hot-pressing facility (Hi-multi 5000, Fuji Dempa Kogyo Co.). The fiber volume fraction $\left(V_{\mathrm{f}}\right)$ of most of the obtained composite was approximately $35 \%$ except for two of the composites for fiber volume examination. The relative densities of these composites hot-pressed at $1200{ }^{\circ} \mathrm{C}$ with $27 \mathrm{vol} \%, 35 \mathrm{vol} \%$ and $41 \mathrm{vol} \%$ fibers were $80 \%, 82 \%$ and $85 \%$, respectively. In order to analyze the fracture behavior of the matrix, an alumina green body containing only the green sheets used for the composite preparation was prepared and hot-pressed at $1200^{\circ} \mathrm{C}$ and $1300^{\circ} \mathrm{C}$ for $1 \mathrm{~h}$.

The sintered specimens were cut into $3.5 \mathrm{~mm} \times 35 \mathrm{~mm} \times$ $\sim 3.5 \mathrm{~mm}$ bars along the $0^{\circ} / 90^{\circ}$ yarn direction for the measurement of their mechanical properties. The bulk density and porosity of the hot-pressed composite were measured by the Archimedes method using water. Care was taken to avoid excessive removal of water from the surface of the porous specimens. Flexural strength was measured at room temperature (RT) in air and high temperature (HT) in vacuum by the three-point flexural method using a universal testing machine (Type 1185, Instron Co., Ltd., USA). The crosshead speed was $0.1 \mathrm{~mm} / \mathrm{min}$ with a span of $30 \mathrm{~mm}$. Before the load was applied for the high-temperature test, the specimens were soaked at the test temperature for $30 \mathrm{~min}$ to obtain temperature uniformity. Maximum strength at a given temperature was the average of three tested specimens. The fracture surface of the composites was observed by scanning electron microscopy (SEM). The phases produced in the coated fabric cloth after heat treatment at $600^{\circ} \mathrm{C}$ and $1300^{\circ} \mathrm{C}$ were analyzed by X-ray diffractometry (XRD).

\section{Results and discussion}

3.1 Properties of composites at room temperature

The back-scattered scanning electron photograph of monazite-coated alumina fibers in the composite hot-pressed at $1200^{\circ} \mathrm{C}$ is shown in Fig. 1 (A). The bright area, i.e., heavier elements, around fibers should be monazite coating. A relatively uniform coating on the fiber surface was confirmed. The thickness of the monazite coating was estimated to be approximately 200-500 $\mathrm{nm}$ using field emission SEM at a high magnification. Fiber debonding and pullout in the composite during fracture are observed as shown in Fig. 1(B). The density of monazite itself was measured to be $5.02 \mathrm{~g} / \mathrm{cm}^{3}$ using the bulk specimen prepared from the slurry for the coating and hot-pressed at $1300^{\circ} \mathrm{C}$. The value is close to the reported theoretical density $\left(5.13 \mathrm{~g} / \mathrm{cm}^{3}\right) .{ }^{1)}$ The XRD patterns of the coated fabric cloths after heat treatment at $600^{\circ} \mathrm{C}$ and $1300^{\circ} \mathrm{C}$ showed that there was no other new phase except for Lamonazite, as shown in Fig. 2. Thus, all fibers in fiber bundles seemed to be coated by a relatively dense crystalline monazite layer.

Details of the room temperature mechanical properties of the composite using coated fibers were described previously, ${ }^{17}$ and are simply summarized as follows. The mechanical properties of the composites were greatly influenced by the sintering conditions, such as sintering temperature and fiber volume fraction. If the sintering temperature was increased, both the density and strength of the composites were improved but the ductility of the composite was suppressed. While the increase in fiber volume fraction caused not only an improvement in maximum strength, but also an improvement in pseudoductility. All composites sintered at a temperature lower than $1250^{\circ} \mathrm{C}$ using coated fibers showed nonbrittle fracture with fiber debonding and pullout. In the case of the composite sintered at
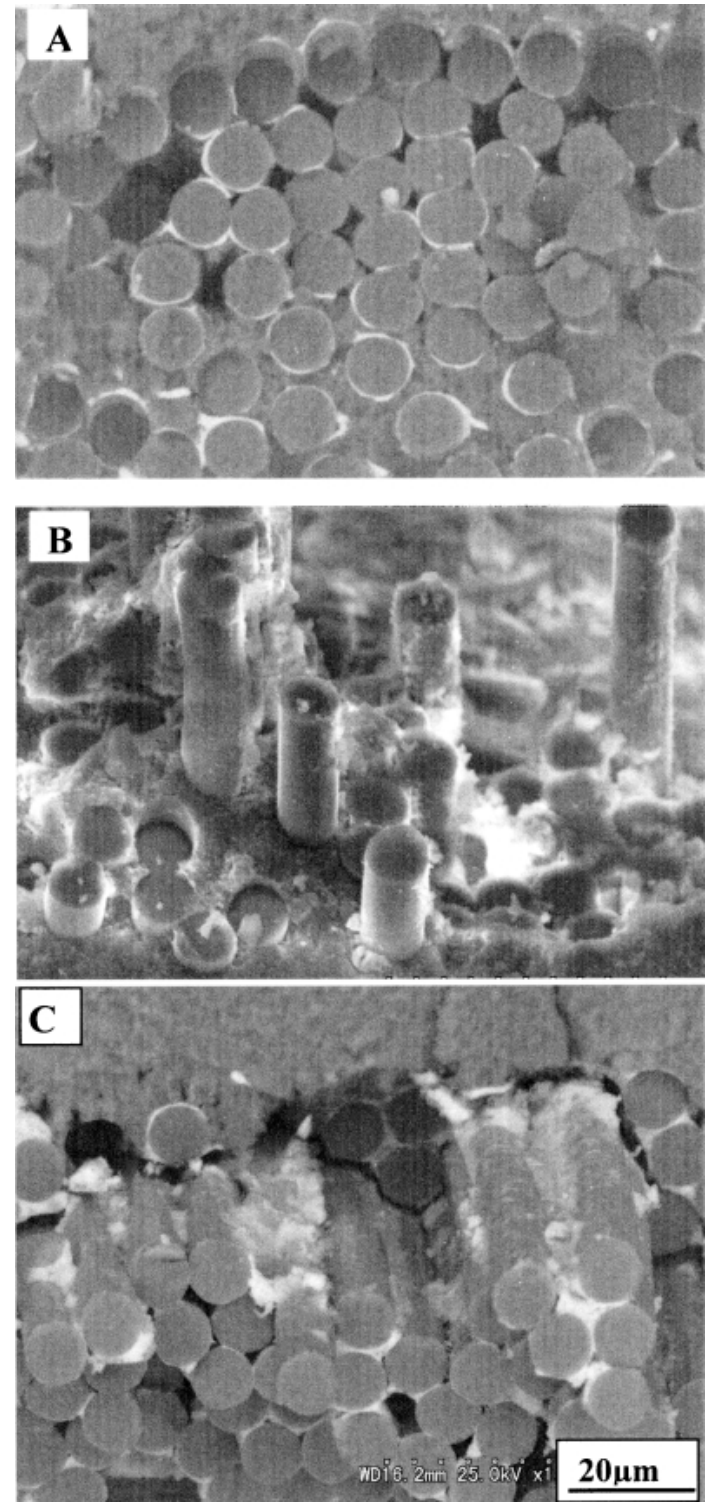

Fig. 1. SEM photographs of fractured surface of the composite hotpressed at $1200^{\circ} \mathrm{C}, 40 \mathrm{MPa}, 1 \mathrm{~h}$. (A) BSE image and (B) normal image, fractured at room temperature. (C) fractured at $1200^{\circ} \mathrm{C}$.

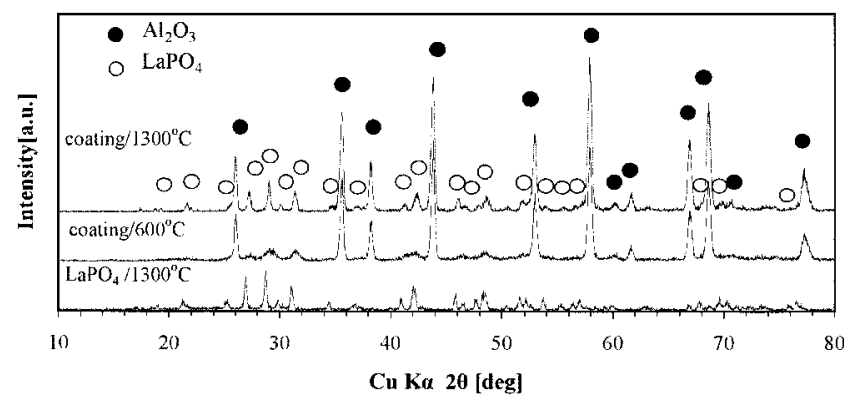

Fig. 2. XRD profiles of monazite-coated fabric cloth after heat treatment at $600^{\circ} \mathrm{C}$ and $1300^{\circ} \mathrm{C}$.

$1200^{\circ} \mathrm{C}$ under $40 \mathrm{MPa}$ for $1 \mathrm{~h}$, fiber debonding and pullout from matrix were observed, as shown in Fig. 1(B). A monazite layer was observed on both pulled-out fiber surfaces and matrix troughs, as shown in Fig. 1(A), suggesting that 


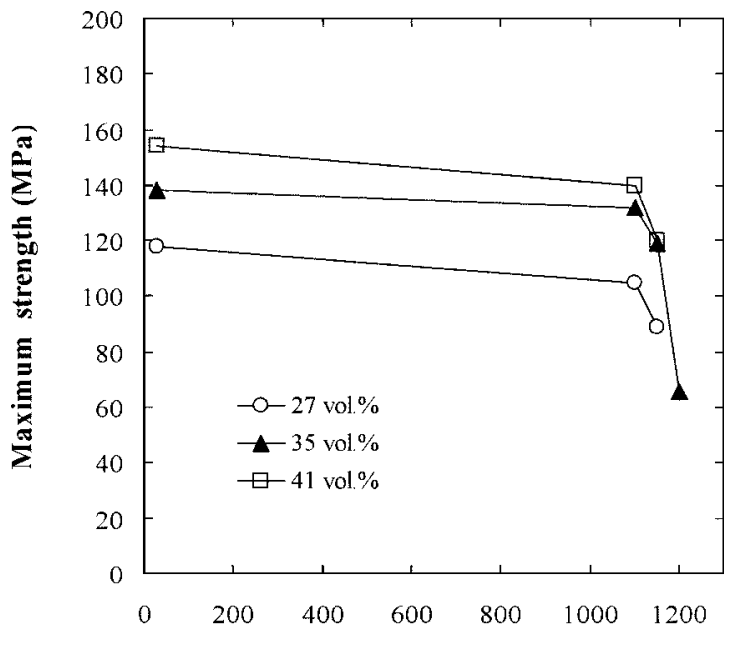

Test temperature ( ${ }^{\circ} \mathrm{C}$ )

Fig. 3. High-temperature maximum strength of composite as a function of fiber volume fraction. These composites were hot-pressed at $1200^{\circ} \mathrm{C}, 40 \mathrm{MPa}, 1 \mathrm{~h}$.

cracks progressed predominantly along the coating surface (coating/fiber or coating/matrix) or within the coating rather than in the matrix. However, the composite sintered above $1250^{\circ} \mathrm{C}$ became brittle even with coated fibers.

3.2 Properties of composite at high temperature

Figure 3 shows the maximum strength of the composites tested at a high temperature. These composite were sintered at $1200^{\circ} \mathrm{C}, 40 \mathrm{MPa}$ for $1 \mathrm{~h}$ with different fiber volume fractions. All composites showed no sufficient strength change from RT to $1100^{\circ} \mathrm{C}$ regardless of fiber volume fractions, but strength decreased markedly at more than $1150^{\circ} \mathrm{C}$. The strength of composites fabricated under the same conditions increased with fiber volume fraction at all measurement temperatures. In order to clarify the states of the fiber and matrix in the composites, the HT strengths of the fiber, the alumina matrix and the composite are compared in Fig. 4. The RT strength of the alumina matrix sintered at $1200^{\circ} \mathrm{C}$ under $40 \mathrm{MPa}$ for $1 \mathrm{~h}$ was $196 \mathrm{MPa}$. At $1100^{\circ} \mathrm{C}$, the strength of the fibers retained more than $60 \%$ RT strength (RT strength of fiber: $3.3 \mathrm{GPa}$ ), ${ }^{18), 19)}$ while the strength of the matrix retained $42 \%$ of RT strength. At $1150^{\circ} \mathrm{C}$, the strength of the matrix was further decreased to $23 \% \mathrm{RT}$ strength. It should be noted that the strength retention value of the fiber was still up to $45 \%$ RT strength at this temperature. Actually fiber strength would be mainly determined during fabrication process temperature of the composite, i.e., 1200 or $1300^{\circ} \mathrm{C}$, and may not largely be influenced by the test temperature below the process temperature. In other words, it is believed that the fiber strength in the composite does not significantly change up to $1200^{\circ} \mathrm{C}$ in the case of the composites shown in Fig. 3, therefore the maximum strength of the composite was retained up to $1100^{\circ} \mathrm{C}$. It is notable that the fibers played a very important role in the HT performance of the composite above $1000^{\circ} \mathrm{C}$, even in the marked decrease in strength of the matrix at this temperature region.

Representative flexure load-displacement curves of the composite with $35 \mathrm{vol} \%$ of fibers tested at different temperatures are presented in Fig. 5. At RT, the composite showed an initial linear region as all of the other composites fabricated in this experiment. After the maximum load-carrying capacity was attained, there was a gradual decrease in load in accordance with fiber pullout from the matrix and the breaking of

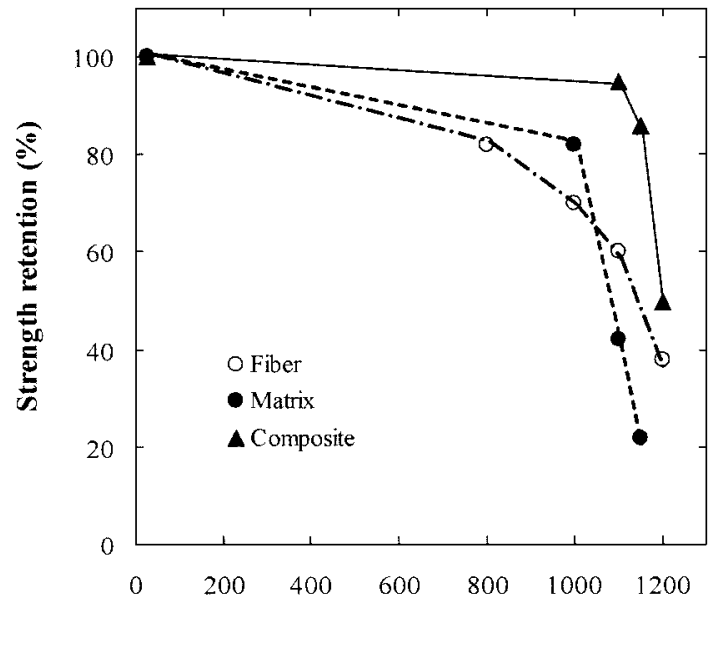

Test temperature $\left({ }^{\circ} \mathrm{C}\right)$

Fig. 4. Strength retention of Nextel 610 fiber, ${ }^{18)}$ a monolithic alumina and $35 \mathrm{vol} \%$ alumina fiber/alumina matrix composite at elevated temperature. The monolithic alumina ceramic and the composites were sintered at $1200^{\circ} \mathrm{C}, 40 \mathrm{MPa}, 1 \mathrm{~h}$.

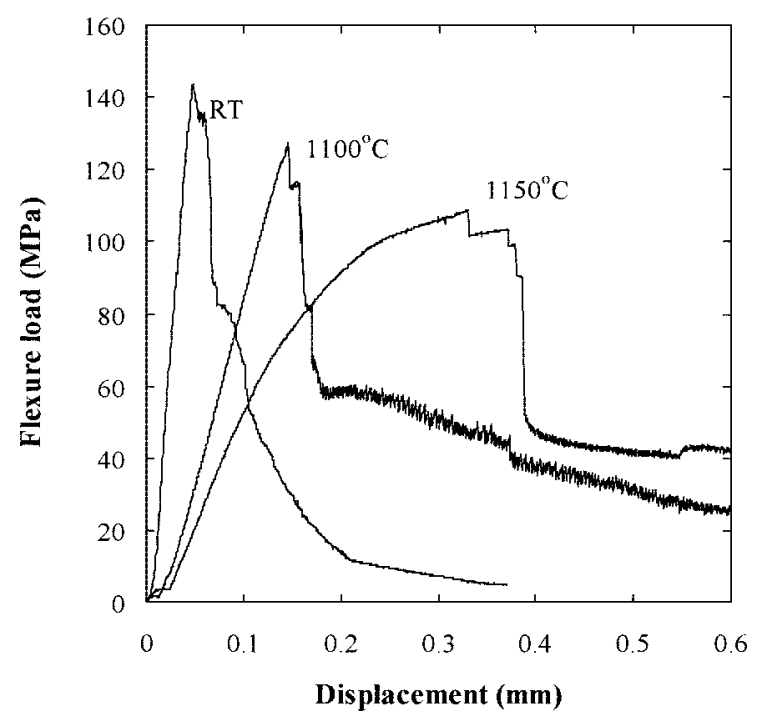

Fig. 5. Flexure load-displacement curves of composite hot-pressed at $1200^{\circ} \mathrm{C}, 40 \mathrm{MPa}, 1 \mathrm{~h}, 35 \mathrm{vol} \%$ of fibers tested at room and elevated temperature.

fibers in the crack-wake region. This behavior is typical for tough fiber-reinforced CMCs and has been observed in detail for this composite in a previous publication. ${ }^{17)}$ The curve obtained at $1100^{\circ} \mathrm{C}$ exhibited the same feature but the elastic modulus of the composite during the increase in load was lower than that of the composite measured at RT. This can be attributed to the gradual decrease in the elastic modulus of the matrix at this temperature. The behavior of the composite tested at $1150^{\circ} \mathrm{C}$ showed a completely different fracture feature. Besides a slightly lower maximum strength than those obtained at lower temperatures, the initial linear region mostly disappeared. After several small steps of load reduction, a large drop of the load was observed. Finally, nearly a constant load was applied for large displacement, indicating plasticlike deformation. The further decrease in the strength of the 
matrix combined with the still higher strength of the fiber correspond to the plastic-like deformation of the composite at this temperature, as mentioned above and indicated in Fig. 4. Monazite in the fiber/matrix interface supplied a weak interface (fracture energy of bulk monazite is $7 \mathrm{~J} / \mathrm{m}^{2}$ ) ${ }^{3}$ ) for fiber debonding and pullout, as shown in Fig. 1(C), which may have enhanced the large deformation of the composite during fracture. It is known that the area under the flexure loaddisplacement curve is proportional to the work of fracture (WOF). In order to evaluate the WOF value at different test temperatures, the following are supposed. The surrounding area of the load-displacement curve with the displacement axis as a work of fracture is denoted as $U_{\text {wof }}$, and $E=U_{\text {wof }} / 2 S$ is the apparent fracture energy, where $S$ represents the crosssectional area of the specimen. At RT, $E$ was calculated to be $0.88 \mathrm{~kJ} / \mathrm{m}^{2}$ for the composite hot-pressed at $1200^{\circ} \mathrm{C}$, and 40 $\mathrm{MPa}$ for $1 \mathrm{~h}$, however at $1100^{\circ} \mathrm{C}$ and $1150^{\circ} \mathrm{C}, E$ became 1.87 $\mathrm{kJ} / \mathrm{m}^{2}$ and $2.34 \mathrm{~kJ} / \mathrm{m}^{2}$, respectively. The fracture energy of the composite markedly increased with the increase in test temperature due to the large deformation of the composites at high temperature.

The maximum strength of the composite hot-pressed at different temperatures and tested from RT to $1200^{\circ} \mathrm{C}$ is shown in Fig. 6. The relative density of the composite sintered at $1300^{\circ} \mathrm{C}$ was $87 \%$, which is clearly higher than that of the specimen sintered at $1200^{\circ} \mathrm{C}(82 \%)$ under the same conditions. The maximum strength of all composites slightly decreased with temperature up to $1100^{\circ} \mathrm{C}$, and decreased markedly at more than $1150^{\circ} \mathrm{C}$ regardless of the sintering temperature. The strength of the composites at elevated temperatures still has the same tendency against sintering temperature as those of composites tested at RT. This indicates that the maximum strength of the composite is mainly determined by the sintering conditions. Flexure load-displacement curves of the composite sintered at $1200-1300^{\circ} \mathrm{C}$ and tested at $1200^{\circ} \mathrm{C}$ are shown in Fig. 7. As mentioned before, the fracture behavior of the composite at RT was completely brittle if the composite was sintered at a temperature higher than $1250^{\circ} \mathrm{C}$, due to the decrease in fiber strength and increase in matrix strength. It is also noted that all composites tested at RT showed an initial linear increase in load with displacement (linear region) till the first crack in the flexure load-displacement curve appeared. However, the initial linear region disappeared when the composite was tested at $1200^{\circ} \mathrm{C}$. This indicates that the elastic modulus of all composites decreases markedly at $1200^{\circ} \mathrm{C}$. For the composite sintered at $1200^{\circ} \mathrm{C}$, large plasticlike deformation was observed. Thus, the plasticlike deformation of the composite seemed to be the principal mechanism of energy dissipation at this temperature.

For the alumina matrix, the sintering temperature to obtain nearly full density $\left(3.96 \mathrm{~g} / \mathrm{cm}^{3}\right)$ is approximately 1300 $1500^{\circ} \mathrm{C}$. Below this temperature, strength should be weakened by porosity in the alumina matrix. Therefore, increasing sintering temperature has been regarded as an effective way to reduce porosity, and then increase density and strength. The higher matrix density in the composites sintered at a higher temperature may be the reason the composites maintained a relativly higher strength than that of the composites sintered at a lower temperature, as shown in Fig. 6. On the other hand, the fiber strength should decrease with increasing sintering temperature, as mentioned above. As a consequence, the relative strength ratio of fiber to matrix should decrease with increasing sintering temperature. Thus, the relatively higher fiber/matrix strength ratio should be the main reason the larger deformation occurred at the test temperature of $1200^{\circ} \mathrm{C}$

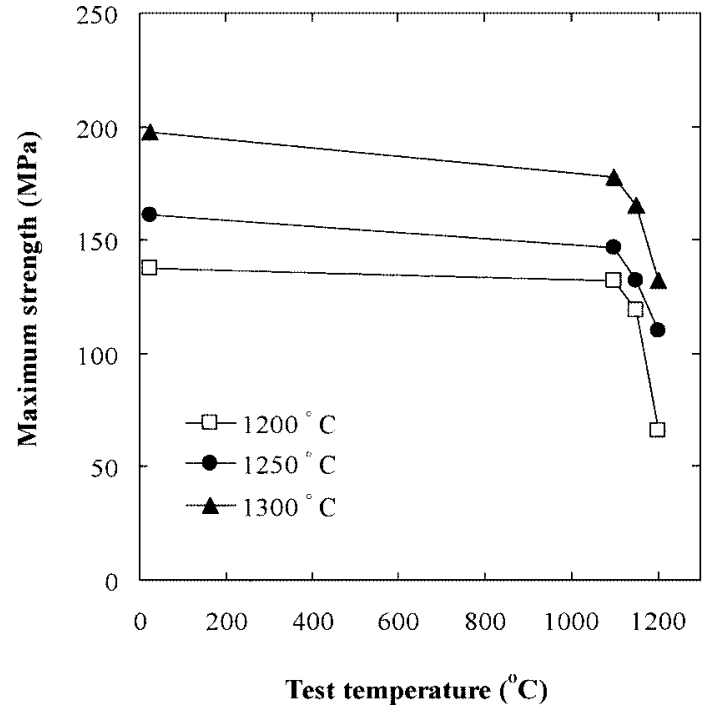

Fig. 6. High-temperature maximum strength of composite $\left(V_{\mathrm{f}}=\right.$ $35 \%$ ) hot-pressed at $1200-1300^{\circ} \mathrm{C}$ under $40 \mathrm{MPa}$ for $1 \mathrm{~h}$ as a function of sintering temperature.

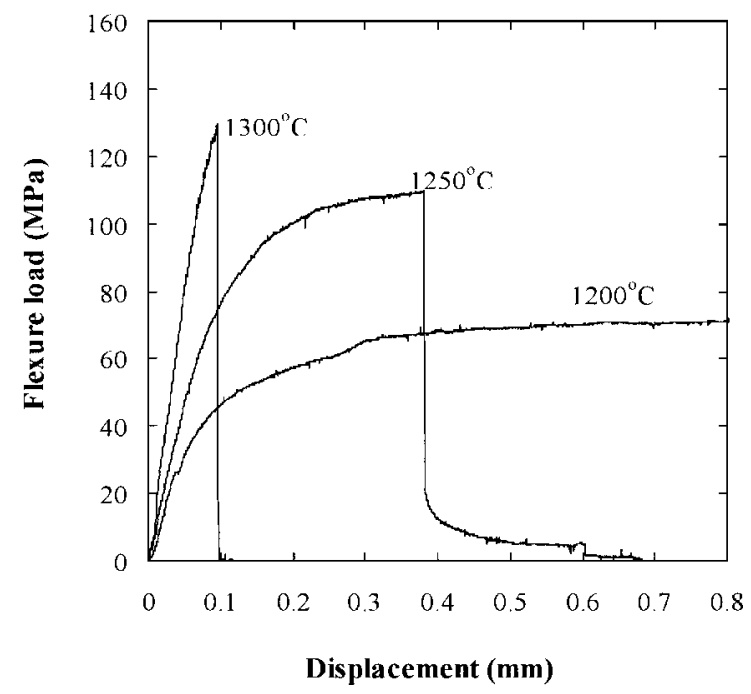

Fig. 7. Flexure load-displacement curves of composite $\left(V_{\mathrm{f}}=35 \%\right)$ hot-pressed at $1200-1300^{\circ} \mathrm{C}$ under $40 \mathrm{MPa}$ for $1 \mathrm{~h}$, and tested at $1200^{\circ} \mathrm{C}$.

for the composites sintered at $1200^{\circ} \mathrm{C}$, as shown in Fig. 7. The composite sintered at $1300^{\circ} \mathrm{C}$ and tested at $1200^{\circ} \mathrm{C}$ showed small in-elastic deformation in the initial region and then complete drop of the load after it reached the maximum stress due to the lower fiber/matrix strength ratio. Another possible reason for the change in fracture mode at $1200^{\circ} \mathrm{C}$ might be attributed to the difference in the size of matrix grains. After higher temperature sintering, i.e., $1300^{\circ} \mathrm{C}$, the average grain size of the matrix $(360 \mathrm{~nm})$ was larger than that of the composite sintered at a lower temperature, i.e., $1200^{\circ} \mathrm{C}(200 \mathrm{~nm})$, as described in another report. ${ }^{20)}$ The yield stress required for creep deformation is strongly related to the grain size of alumina, ${ }^{21)-23)}$ i.e., larger grain size corresponds to lower creep rate. Thus the difference in composite performance in the $1200^{\circ} \mathrm{C}$-test with sintering temperature should correspond to the differences in fiber/matrix strength ratio and in the grain 

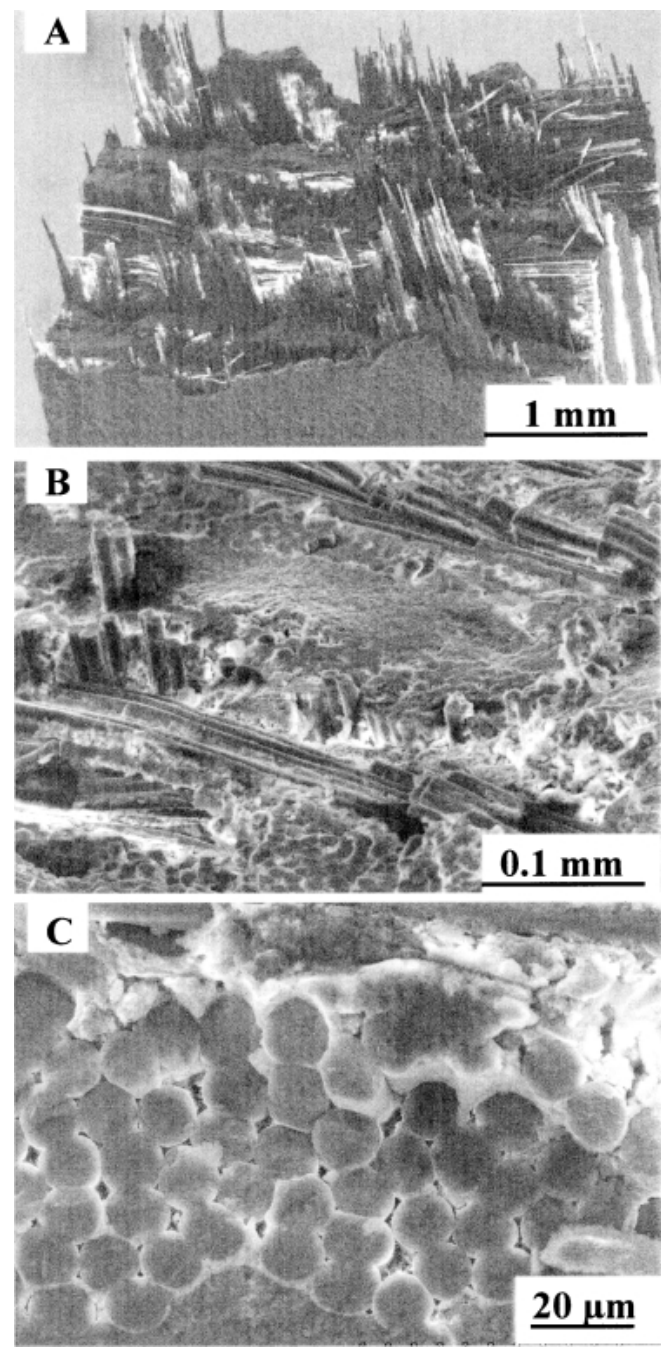

Fig. 8. Fracture surface of composite shown in Fig. 7 after fracture at $1200^{\circ} \mathrm{C}$. These composites were hot-pressed at (A) $1200^{\circ} \mathrm{C}$, (B) $1250^{\circ} \mathrm{C}$, and (C) $1300^{\circ} \mathrm{C}$.

size of the matrix of the composite.

The total area under the flexure load-displacement curve of the composite hot-pressed at $1200^{\circ} \mathrm{C}$ and tested at $1200^{\circ} \mathrm{C}$ was significantly larger than those of the composite hot-pressed at $1250^{\circ} \mathrm{C}$ or $1300^{\circ} \mathrm{C}$ and tested at the same temperature, indicating that the fracture energy decreased with increasing sintering temperature at a high test temperature. This tendency was the same as that measured at room temperature. The fracture surface of the composite hot-pressed at $1200^{\circ} \mathrm{C}$ and tested at $1200^{\circ} \mathrm{C}$ shows extensive fiber pullout with a longer length than that of the composite tested at RT, as shown in Fig. $8(\mathrm{~A})$. This indicates that large deformation (i.e., lower strength) of matrix should enhance fiber debonding. In the case of the composite sintered at $1250^{\circ} \mathrm{C}$, the composite still showed nonbrittle features as it was measured at RT. Fracture surface observation indicated pullout of a few fibers from the matrix with limited length, as shown in Fig. 8(B). The composite sintered at $1300^{\circ} \mathrm{C}$ and tested at $1200^{\circ} \mathrm{C}$ exhibited mostly brittle fracture probably due to fiber degradation during the sintering process. The composite had the lowest in-elastic deformation as well as the smallest total area under the flexure load-displacement curve among the three composites hotpressed at $1200-1300^{\circ} \mathrm{C}$. SEM photograph in Fig. $8(\mathrm{C})$ shows that fibers were separated by the coating, but no obvious fiber-pullout could be observed. Thus, it is concluded that the sintering process dominates the fracture properties of the composite at both room and elevated temperature, since fiber properties are very temperature-dependent at more than $1200^{\circ} \mathrm{C}$. Fiber-pullout feature would be decided mainly by the combination of matrix strength and fiber strength. If fiber degradation took place and densification of matrix progressed during sintering at a higher temperature, the ductility of composites should be reduced regardless of test temperature.

\section{Conclusion}

The high-temperature mechanical properties of monazitecoated alumina-fiber/alumina-matrix composite were examined. All of the examined composites had a similar strength when measured from $\mathrm{RT}$ up to $1100^{\circ} \mathrm{C}$ regardless of sintering conditions and fiber volume fraction. Above this temperature, the maximum strength of the composite decreased rapidly. The fracture behavior of the composite hot-pressed at a temperature lower than $1250^{\circ} \mathrm{C}$ changed markedly at a high test temperature. Fracture energy increased and elastic modulus decreased with increasing test temperature, at the same time, the deformation behavior of the composites changed from pseudoductile to plasticlike in manner. For the composite hotpressed at a temperature higher than $1250^{\circ} \mathrm{C}$, ductility markedly decreased at both room and high temperature even using the coated fibers, since the decrease in fiber strength and the increase in the strength of the matrix layers. It seems that the fiber debonding and pullout are mainly determined by the sintering process, and no obvious change with the test temperature was observed, i.e., the brittle composites at room temperature are still brittle at high temperature, and the high pseudoductile composite still high at high temperature.

Acknowledgements We wish to thank the Grant-in-Aids for Scientific Research from JSPS for their generous financial support.

\section{References}

1) Morgan, P. E. D. and Marshall, D. B., J. Am. Ceram. Soc., Vol. 78, pp. 1553-1563 (1995).

2) Holmquist, M., Lundberg, R., Sudre, O., Razzell, A. G., Molliex, L., Benoit, J. and Adlerborn, J., J. Eur. Ceram. Soc., Vol. 20, pp. 599-606 (2000).

3) Marshall, D. B., Davis, J. B., Morgan, P. E. D. and Porter, J. R., Key Eng. Mater., Vol. 127-131, pp. 27-36 (1997).

4) Marshall, D. B. and Davis, J. B., Current Opinion in Solid State \& Materials Science, Vol. 5, pp. 283-289 (2001).

5) Kerans, R. J., Hay, R. S., Parthasarathy, T. A. and Cinibulk, M. K., J. Am. Ceram. Soc., Vol. 85, pp. 2599-2632 (2002).

6) Hay, R. S. and Boakye, E. E., J. Am. Ceram. Soc., Vol. 84, pp. 2783-2792 (2001).

7) Boakye, E., Hay, R. S. and Petry, M. D., J. Am. Ceram. Soc., Vol. 82, pp. 2321-2331 (1999).

8) Markys, G., Cain, R. L., Cain, R. L., Tye, A., Rian, P., Lewis, H. and Gent, J., Key Eng. Mater., Vol. 127-131, pp. 37-50 (1997).

9) Cazzato, A., Colby, M., Daws, D., Davis, J., Morgan, P., Peter, J., Butner, S. and Jurf, B., Ceram. Eng. \& Sci. Proc., Vol. 18, pp. 269-277 (1997).

10) Hwang, T. J., Hendrick, M. R., Shao, H., Hornis, H. G. and Hunt, A. T., Mater. Sci. \& Eng. A, Vol. 244, pp. 91-96 (1998).

11) Koopman, M., Duncan, S., Chawla, K. K. and Coffin, C., Composite: A, Vol. 32, pp. 1039-1044 (2001).

12) Davis, J. B., Marshall, D. B. and Morgan, P. E. D., J. Eur. Ceram. Soc., Vol. 20, pp. 583-587 (2000).

13) Keller, K. A., Mah, T., Parthasarathy, T. A., Boakye, E. E., Mogilevsky, P. and Cinibulk, M. K., J. Am. Ceram. Soc., Vol. 
86, pp. 325-332 (2003).

14) Keller, K. A., Mah, T., Parthasarathy, T. A. and Cinibulk, M., Ceram. Eng. \& Sci. Proc., Vol. 22, pp. 667-675 (2001).

15) Lee, P. Y., Imai, M. and Yano, T., Composites Interfaces, Vol. 11, pp. 1-13 (2004).

16) Lee, P. Y. and Yano, T., J. Ceram. Soc. Japan, Suppl., Vol. 112, S333-S337 (2004).

17) Lee, P. Y., Imai, M. and Yano, T., J. Ceram. Soc. Japan, Vol. 112, pp. 29-34 (2004).

18) Wilson, D. M., "High Temperature Ceramic Matrix Composites," Wiley-VCH, Weinheim, Germany (2001) pp. 3-12.

19) Schmucker, M., Flucht, F. and Schneider, H., "High Tempera- ture Ceramic Matrix Composites," Wiley-VCH, Weinheim, Germany (2001) pp. 73-78.

20) Yano, T. and Lee, P. Y., "High Temperature Ceramic Matrix Composites 5," Ed. by Singh, M., Kerans, R. J., Lara-Curzio, E. and Naslain, R., Am. Ceram. Soc. (2004) pp. 247-252.

21) Cannon, R. M., Phodes, W. H. and Heuer, A. H., J. Am. Ceram. Soc., Vol. 63, pp. 46-53 (1980).

22) Heuer, A. H., Tighe, N. J. and Cannon, R. M., J. Am. Ceram. Soc., Vol. 63, pp. 53-58 (1980).

23) Ruano, O. A., Wadsworth, J. and Sherby, O. D., Acta Materialia, Vol. 51, pp. 3617-3634 (2003). 